e-makâlât Mezhep Araştırmaları, VII/2 (Güz 2014), ss. 129-148.

ISSN 1309-5803 | www.emakalat.com

\title{
CEZAYIR METODOLOJİ ENSTİTÜSÜ MÜDÜRÜ PROF. DR. MUHAMMED BABAAMMÎ İLE “İBÂDÎ VE İBÂDÎLERLE İL- GİLI MESELELER” BAŞLIKLI SÖYLEŞİ
}

\author{
Mehmet Mahfuz SÖYLEMEZ ${ }^{1}$
}

\begin{abstract}
Öz
Muhammed Babaammî aslen Cezayirli olup İbâdî kökenli bir ilim adamıdır. Araştırmalarının önemli bir kısmı İbâdîlerle ilgilidir. Aynı zamanda bir muhakkik olan Muhammed Babaammî, bu mezhebe ait birçok yazmayı tahkik ederek yayınlamıștır. Kendisini İslami ilimler Dergisi olarak Çorum'a davet ettik. Ve okumakta olduğunuz söyleşiyi 02/11/2013 tarihinde, dergimizin sahibi olan Çorum Çağnı Eğitim Vakfı'nın himayesinde Turgut ÖZAL Konferans salonunda gerçekleştirdik. Tarafımdan tercüme edilen bu söyleşi, doğası gereği bazı tekrarlar da içermektedir. Onlara da dokunulmamış, olduğu gibi bırakılmışlardır.
\end{abstract}

Mehmet Mahfuz SöYLEMEZ: Aziz dinleyiciler sözlerime başlarken hepinizi hürmetle selamliyorum. Efendim malumunuz olduğu üzere günümüzde İslam âleminde dört İslam mezhebi yaşamaktadir.

1-Ehl-i Sünnet: Bu mezheplerin en büyüğüdür.

2-Zeydiyye

3-İsna Aşeriyye veya Ca’feriyye

4-İbâdîyye.

Günümüzde yaşayan İslam mezhepleri içerisinde en az bildiğimiz ise İbâdîyyedir. Hakkında o kadar az bilgimiz var ki bazen sınıfta öğrencilerime yaşayan İslam mezheplerinden bahsettiğimde İbâdîyyeyi sayarken yüzüme hayretle baktıklarını görürüm. Çünkü bu

1 İstanbul Üniversitesi İlahiyat Fakültesi Öğretim Üyesi. mehmetmahfuz@gmail.com 
düşünce akımının yaşadığını bilmemektedirler. Ümmetin çok zor günlerden geçtiği hepimizin malumudur. İslam coğrafyasında yaşanan çekişme, çatışma hatta savaş hali bize ümmeti oluşturan parçaların birbirini ne kadar az tanıdığını ortaya koymaktadır. Birbirimizi az tanıdığımız için kolay bir şekilde [manipüle edilebilmekte], rahatlıkla yekdiğerimizi öteki ilan edip düşman haline getirebilmekteyiz. Bütün bu bölünmüşlük ve aymazlıktan kurtulmak için de ümmeti tanımak gerekiyor. İşte bu nedenden dolayı ümmetin bir parçası, hatta önemli bir parçası olan İbâdîleri tanıyalım ve elbette siz kıymetli okurlarımıza da tanıtalım istedik. Masa başında, yazılı materyale dayanarak bir betimleme yapabilirsiniz. Ancak sizin yani dışardan biri olarak yaptığınız bu tasvir gerçekten hakikate ne kadar uyar? Onun için bizzat kendilerinden dinlemek istedik ve bundan dolayı da kendisi de bir İbâdî olan Muhammed BABAAMMî hocamızı buraya davet ettik. Hocamız da davetimizi kabul etti. Huzurunuzda kendisine teşekkür ediyor ve hoşgeldiniz diyorum.

Muhammed Babaammî benim tanıdığım ender insanlardan bir tanesi, genç ama bu genç yaşına rağmen iyi bir tetebbuata sahip. Yüksek lisans ve doktorasını Cezayir'de ve hiç alışkın olmadığımız bir konu üzerinde yapmış: "zaman mefhumu". Bizim en çok sıkıntı hissettiğimiz, çoğunlukla hiç itibar etmediğimiz, hiç değerini bilmediğimiz bir mevzu. Doktorasını bitirdikten sonra kendisini İbâdî kaynaklarına adamış. İbâdîlere ait, günümüze ulaşan birçok yayınlanmamış eser bir başka ifade ile "mahtuta" bulunmaktadır. Yakın zamanda rahmetli Seyyid Kutub'un dostlarından biri olan bir zatın, Amr Halife en-Namî'nin bir kitabını okudum: Dirasâtu'l-íbâdîyye. $\mathrm{Bu}$ eser en-Namî’nin doktora tezi. O bize İbâdîlere ait ne kadar çok yayınlanmamış mahtutanın bulunduğunu; ancak bizim bunların farkında olmadığımızı; genelde bizim dışımızdaki insanların bunları çalıştığını ortaya koyuyor. Söz konusu bu durumdan dolayı da hem seçtiğimiz konu, hem de konuğumuz oldukça önemlidir.

Baammi hocanın tahkik eserleri dışında telif çalışmaları da bulunmaktadır. Bu eserlerden özellikle ikisi son derece önemlidir. Bunlardan ilki el-Mustalahatu'l-İbâdîyye yani İbâdî terminolojisi diğeri ise el-A'lam el-İbâdîyye yani Meşhur İbâdîler adını taşımakta- 
dır. Her iki çalışma da İbâdîler konusunda son derece önemli bir yerde durmaktadır. Dolayısıyla Babaammî hoca bu alanın uzmanı. Onun için biz bu gece alanın uzmanı olan bir zatı dinleyeceğiz. Bize çok ciddi katkılar sağlayacağına inanıyorum. Sorularınız olabilir, bizim sorularımızdan sonra size sorularınızı sormanız için fırsat tanıyacağım.

Evet değerli hocam öncelikle Çorum'a hoş geldiniz. Bildiğiniz gibi Türkiye'deki Müslümanlar olarak İbâdîyye hakkında gerçekten çok az bilgimiz bulunmaktadır. Belki İbâdîyye'nin siyasi hayatı ile ilgili az dahi olsa baz1 malumata sahibiz, ancak ilim ve kültür hayatlarını yeterince bildiğimiz söylenemez. Bu vesileyle bu akşam burada gerçekleştireceğimiz söyleşi bizim için çok önemeli. Arzu ederseniz önce İbâdîyye'nin doğuşu ile başlayalım, sonra bu mevzulara girelim. İlk sorum şu olsun “İbâdîlik tarih sahnesine nasıl çıktı? Söz sizde üstadım.

Muhammed BABAAMMí: Bismillahirrahmanirrahim. Allah'in elçisine salât ve selam olsun. Baylar ve bayanlar! Allah'in selamı üzerinize olsun. Dün gece indiğimiz ve bu gece ayrılacağımız Çorum'u sevgi dolu ve sicak bir ortam olarak bulduğumu söyleyip hepinize teşekkür ederek sözlerime başlamak isterim.

"İbâdî Mezhebi veya İbâdî Okulu", şu [hatırlatmayı yapmama müsaade edin] İbâdî kelimesinde var olan harf "eliftir", "ayın harfi" değildir. Bu kavram mezhebin müessisi ol[duğu söylenen] Abdullah b. İbâd'a nispet edilmektedir. İslam kültüründe zaman zaman baz1 hareketler veya icraatlar onu yapana değil, babasına nispet edilir, örneğin Emevî devleti böyledir. Ataları olan Benî Ümeyye'ye nispet edilmiştir.

İbâdî mezhebinin ortaya çıkması aslında dinî olmayıp saf siyasî bir hadisedir. Zira mezhebin ortaya çıkışını sağlayan durum dinî ihtilaf olmayıp tamamen siyasî bir ihtilaftır. İbâdîyye özellikle Benî Ümeyye'nin başlangıç döneminde -özellikle de- Raşid halifeler döneminin ortadan kalkmasından sonra, bazı siyasi çekişmeler meydana gelince, siyasî bir hadise olarak neşet etmiştir. Ancak İbâdî mezhebini kuran zat aslında Abdullah b. İbâd değildir. Abdullah b. 
İbâd sadece mezhebin resmi ve siyasî sözcüsüdür. Mezhebi kuran şahıs, tabiinden olan Cabir b. Zeyd et-Temimî el-Ezdî'dir. Tabiinden olan Cabir b. Zeyd, Hz. Aişe ve İbni Mesud'dan eğitim almıştır. Rivayetlere göre yetmiş dolayında sahabeye talebelik yapmıs, onlardan dersler almıştır. Tarih kitaplarında Ona atfedilerek rivayet edilen meşhur, güzel bir ifade bulunmaktadır. Diyor ki "Ilimle dopdolu bir deniz olan Abdullah b. Abbas'a gelinceye kadar, Bedir savaşina iştirak eden yetmiş sahabînin ilmine sahip oldum." Bildiğiniz gibi İbâdîyye bir prensip olarak, hilafetin miras yoluyla atadan evlada geçiş sistemini reddetmektedir. [Onların ortaya çıkışını hazırlayan temel amil işte bu düşünceleri olmuştur.] Ancak usul, fikıh, kelam gibi diğer mevzulara baktığımızda İbâdîyye ile Ehl-i Sünnet arasında birçok konuda ciddi bir tetabuk olduğunu görürsünüz. Özellikle de kaynaklar noktasında: Zira İbâdîyye İmam Buharî̀nin Câmius'sSahihî, İmam Müslim'in hadis kitabını ve akaid ile ilgili Ehl-i Sünnet'in kaynaklarının birçoğunu kabul etmekte, onları referans olarak kullanmakta ve istidlal ederken söz konusu bu kaynaklara dayanmaktadır. Bu noktada İbâdîyye ile diğer mezhepler ve özelliklede Ehl-i sünnet arasında bir ihtilaf söz konusu değildir. Yine İbâdîyye'nin sahabeye bakışı da böyledir. Bazı mezhepler sahabeye olumsuz bakarlarken, [onları ta'n edip seb ederken] İbâdîyye böyle yapmamakta, sahabeye değer vermektedir. İbâdîyye sahabenin hata yapabileceğini kabul etmekle birlikte bu hatalara bir içtihat farklılığ olarak bakmaktadır.

Daha önce ifade ettiğim gibi Abdullah b. İbâd, Emeviler ile siyasi meselelerde ters düşüp onlarla mücadele ettiği için bu düşünce akımına "İbâdî Mezhebi" denilmiştir, yoksa işin başlangıcında mezhebe İbâdî Mezhebî denilmiyordu. O dönemde mezhep, Ehlu'dda'va, Ehlu'l-İstikame, Ehlu'l-Hak olarak isimlendiriliyordu. [Dolayısıyla] önceleri bir şahsa nispet edilmiyordu, [az önce zikrettiğim isimlerle] tesmiye ediliyordu. [Anlaşıldığı üzere] onlara İbâdî diyenler kendileri olmayıp muarızlarıdır.

İbâdî Mezhebî Basra'da doğmuştur. Nass'dan yani Nassın [yaygıın olarak bulunduğu] Mekke ve Medine'den uzakta neşet etmiştir. Bu açıdan özellikle fikhi meselelerde Hanefi mezhebine çok benzemek- 
tedir. Hanefî mezhebinin en belirgin özelliği istihsan, mealata itibar, mekasid, hadisin azlığı, hafiyenin bulunmayışı gibi mevzulardır. Bunlar aynı zamanda İbâdî mezhebinin de en belirgin özellikleridir. Kelam noktasında İbâdîler daha çok Maturidilere yakın olarak kabul edilmektedirler. Özellikle Allah'ın sıfatları ve onların tevili meselesi ve benzeri hususlarda Maturidiyye ile İbâdîyye arasında çok büyük benzerlikler mevcuttur.

İbâdîler tarih sahnesine çıktıkları dönemde aynen Hariciler gibi Emevileri reddettiler ve onlardan uzaklaştılar. Ancak Hariciler bu konuda aşırıya kaçtılar ve kendilerinin dışındaki insanları tekfir edip din diş1 olarak kabul ettiler ve onların öldürülmesini caiz olarak gördüler. Ancak İbâdîler böyle yapmadılar. İşte İbâdîlerle Haricilerin [Emevilere karşı aynı tavrı belirlemiş olmaları] bazı tarihçilerin bu iki akımı karıștırmalarına ve İbâdîleri de Harici olarak isimlendirmelerine neden olmuştur. Bildiğiniz gibi Haricilerin Ezerika, Necedat gibi fırkaları vardır ki -Sufriye'nin bu iki fırka ile alakasını bir tarafa bırakalım- bu firkalar aşırı gruplardı. İbâdîyye bunlarla niza' yaşamakta, onların delillerini reddetmektedir. [İbâdiyye onların aksine] Müslüman bir imama karşı huruç etmeyi reddetmekte ve bir Müslümanın katledilmesini benimsememektedir. [İbâdîlerin tarih sahnesine çıktığı dönemi] bu gün içinde yaşadığımız şartlara, [yani] bu fitne dönemine benzetmeme izin verin.

[Günümüzde de Müslümanlara yöneltilen] töhmetler dini olmaktan öte "irhab" yani terör gibi siyasi suçlamalardır ki bunu izah edeceğim. Bu gün İslam adına hareket ettiğini söyleyen bazı şahıslar vardır. Bunlar diğer insanların kanını akıtmakta, onları öldürmektedirler. Bu da "terör" olarak isimlendirilmektedir. Evet, bunun böyle olduğu ortada olup açıkça bilinmektedir. [Ancak sadece bununla yetinilmeyip] daha sonra din ile alakası olan, namaz kılan, tesettüre önem veren, İslamî hassasiyete sahip olanlar da "terör kavramına" dâhil edildiler ve "terörist" olarak ilan edildiler. İşte İbâdîler de aynen bu şekilde Harici olarak isimlendirilmişlerdir. Oysaki [bir kez daha ifade etmeliyim ki] İbâdîler Haricilerin aksine hâkim imama karşı hurucu kabul etmeme, tekfiri reddetme, yol kesmeyi haram kabul etme ve insanların öldürülmesini caiz kabul 
etmeme, evet bütün bunların hepsinde aynen Ehl-i Sünnet gibi [inanmaktadırlar. Bunları] haram olarak kabul etmektedirler.

İbâdîlerin ilk [önemli] şahsiyetinin Cabir b. Zeyd olduğunu zikretmiş ve onunla ilgili bazı bilgiler aktarmıştım; ikinci şahsiyetlerinin ise Abdullah b. İbâd olduğunu ifade etmiştim. İbâdî kültüründe en etkili üçüncü isim ise kuşkusuz İmam Ebû Ubeyde Müslim b. Ebî Kerime'dir. Cabir b. Zeyd hicri 93 tarihinde -bazıları ise bunun hicri 96 tarihi olduğunu söylerler- vefat etmiş iken, Abdullah b. İbâd hicri 87 yllında vefat etmiştir. Ebû Ubeyde ise onlardan bir süre sonra tarih sahnesine çıkmış olup onların talebesidir. Ebû Ubeyde, Basra'da Serdab [denilen medresesinde] Kuzey Afrika ile İslam coğrafyasının doğusundan gelen bazı talebeleri eğitmiştir ki bu uzun bir meseledir. Ebû Ubeyde, doğal olarak, Emevîlere tehdit olarak görüldüğü için onlar tarafindan benimsenmemiştir. Bundan dolayı gizli gizli ders veriyordu ki, onun ders verdiği yer dışardan sepet atölyesi olarak görünüyordu. Bundan dolayı da kendisine "Kaffâf" yani sepetçi deniliyordu. Ebû Ubeyde'nin medresesinde yetişen talebelerin bir kısmı Kuzey Afrika'ya bir kısmı da İslam coğrafyasının doğusuna gönderildiler. İşte İbâdîyye [Ebû Ubeyde tarafından yetiştirilen] ve adına Talebetu'l-ilm denilen [bu dailer aracıl1ğıyla] İslam coğrafyasına yayıldı. Maşrik’ta ilk İbâdî yapılanma veya bağımsız devlet, Yemen'in Hadramevt bölgesinde kuruldu. Buna Tâlibu'1-Hak Abdullah b. Yahya devleti denilmektedir. Bu devlet, hicri 130 yılı dolaylarında kurulmuştur. Mağrib yani [Kuzey Afrika'da] ise uzun süren çabalar neticesinde, Rüstemiler adıyla bilinen bir devletin Cezayir'de Tahert'te, kurulması sağlanmıştır. Ki bu devlet 160 ile 296 tarihleri arasında tarih sahnesinde kalmıştır. Rüstemi Devleti ile ilgili tabi ki birçok çalışma yapılmıştır. Müslümanlar, hatta Oryantalistler de bu devlet üzerinde çokça çalışmışlardır. $\mathrm{Bu}$ devlet hoşgörüsü ile tebellür etmiştir. Çeşitli gurupların barış içinde bir arada yaşayabilmesine örnek olarak zikredilen bir devlet olmuştur. Hatta Rüstemi Devleti'nin bizzat kendi tarihini yazan şahısın kendisi de o dönemde yaşayan ancak İbâdî olmayıp Maliki Mezhebi'ne mensup olan İbn Sağir el-Malikî'dir. Onun Tarihu Devleti'r-Rüstemiyye adında bir kitabı vardır. İbn Sağir bu eserinde Rüs- 
temilerin vatandaşlarına karşı hoşgörülü olduklarını, devlet içerisinde yaşayan değişik gurupların bir arada ve diyalog içerisinde hayatlarını idame ettirdiklerini anlatmaktadır. Rüstemi Devleti az önce ifade ettiğimiz gibi hicri 296 tarihinde Şiî Fatımiler tarafından, Fatımilerin Kuzey Afrika'ya yayıldıkları esnasında yıkılmıştır. Rüstemî Devleti'nin yıkılışından günümüze kadar İbâdîler tarafından Kuzey Afrika'da hiçbir siyasi oluşum gerçekleştirilememiştir. [Bir başka ifade ile] onlar adına hiçbir siyasi yapılanma teşekkül etmemiştir. Maşrik yani doğuya gelince İbâdî İmamet daha sonra Umân'a intikal etmiş ve miladi 1959 yılına kadar da burada varlığ1nı korumuş ve "İbâdî imamet" olarak anılmıştır. Her ne kadar günümüzde Umân Sultanlığı olarak tesmiye edilse de daha önce buras1 "İmamet" veya "Uman İmameti" olarak isimlendiriliyordu. Günümüz Umân Sultanlığı'nın büyük bir kısmını İbâdîler oluşturmaktadır. Keza Umân'da önemli oranda Sünni (Şafii) ve küçük bir grup Şii de yaşamaktadır. Umân'a gidenler orada bu mezhepler arasında bir diyaloğun varlığını görürler. Uman İbâdîleri bir arada yaşama kültürüne sahiptirler. Medyada gördügümüz mezhepler arası çatışma Umân'da yaşanmamaktadır.

Kuzey Afrika'ya gelince az önce de ifade ettiğim gibi İbâdîler, Rüstemi devletinin yıkılışından sonra siyasi bir birlik veya oluşum kuramadilar. Ancak sosyal birlikler teşkil ettiler. Bir başka ifade ile İbâdî cemaatin eğitimi ve toplumsal yapısına hizmet eden birlikler oluşturdular. Bu hizmetleri gerçekleştirirken hep orada hâkim olan devletlerle koordineli bir şekilde, onlarla yardımlaşarak hareket ettiler. Hatta İbâdîler, Kuzey Afrika Osmanlı Devleti'nin hâkimiyetinde iken de aynen bu şekilde davranmıştır. Osmanlı dönemine ise biraz sonra değineceğim.

Rüstemi Devleti Cezayir'in batısından Tahert dolaylarından başlayıp Doğu'da Libya'nın Trablus sahillerine; Güneyde ise Mali ve bazı Afrika içlerine kadar uzanan [geniş bir coğrafyayı hâkimiyetleri altına almıştı]. Maşrık [yani doğuya] gelince az önce de ifade ettiğim gibi Umân Sultanlığ,1 İbâdî mezhebine mensuptur. Onların yanı sıra Zengibar adası ve bazı Güney Afrika ülkelerinde de İbâdî mezhebine mensup Müslümanlar yaşamaktadır. Uman toplumu aslında tüccar 
ve özelliklede denizci bir toplumdur. Öyle ki Umân'a ait bir donanma mevcut idi. Hatta meşhur İbn Macit de aslen Umânlıdır. İşte onlar bu özellikleriyle İslam'ın, değişik bölgelere ulaşmasını sağladılar. İslam'n Çin, Hindistan, Malezya, Kalkuta bölgesinde yayılmas1na yardımcı oldular. Keza Kuzey Afrika, özellikle Afrika'nın batı bölgesine ve hatta Endülüs'e İbâdîlikle [birlikte] İslâm'in yayılmasını da sağladılar. Ki "Endülüste İbâdîlik" konusu ile ilgili bazı çalışmalar da yapılmıştır. Az önce İbâdîlerin, yaşadıkları Kuzey Afrika'da oraya hakim olan Müslüman devletlerin yöneticileri ile koordineli bir şekilde çalıştıklarını söylemiştim. İbâdîler, onların hamiyetinde varlıklarını sürdürmektedirler. Onların otoritesini tanımakta, kendilerini tekfir etmemektedirler. [Önemli olduğunu düşündüğüm bu] mevzuya biraz sonra daha ayrıntılı bir şekilde değinmeye çalışacağım.

Bildiğiniz gibi Osmanlı döneminde -özellikle Yavuz Sultan Selim döneminde- Hristiyan haçllar, -özellikle de İspanyalılar- Kuzey Afrika sahillerine, -özellikle de Cezayir ve Tunus dolaylarına- yönelik saldırılarda bulunmaya başlamışlardı. O dönemde aslen Cezayirli olan Oruç Reis ile Barbaros Hayrettin Paşa kardeşler Akdeniz'de bir donanma oluşturdular ve Afrika'nın Kuzeyini Hristiyan haçlı tehdidinden kurtararak özgürlüğüne kavuşturdular. Sizin de bildiğiniz gibi Cezayir nüfusunun çoğunu Maliki Mezhebine mensup Müslümanlar oluşturmaktadır. İbâdîler, Cazayir'de çok küçük bir kitleyi teşkil etmektedir. Osmanlı döneminde hem Malikiler ve hem de İbâdîler Osmanlının bölgedeki varlığını kabul ettiler ve bunu bir İslâm hilafeti olarak gördüler. Osmanlının bölgeye gelişini Cezayir'e bir saldırı olarak görmediler. Günümüze kadar da bu böyle devam etti. Hatta hiçbir ders kitabında o dönemden "Osmanlı sömürgesi" şeklinde bahsedildiğine tanık olamazsınız, tam tersine Cezayirliler Osmanlı dönem[ini sahiplenir ve bu dönemle] gurur duyarlar ve böylece $\mathrm{O}$ dönemden bir sömürge dönemi olarak asla bahsetmezler.

Osmanlının Cezayir'e girdiği dönemde İbâdîlerden bahsedecek olursak onlar [aynen Malikiler gibi] Oruç Reis ile Barbaros Hayrettin Paşa'ya sevgilerini ve bağl1lıklarını bildirdiler, onlarla ittifak kurup, kendileriyle bir vela ilişkisi içerisinde oldular. İbâdîlerin Osmanlı ile ilişkileri daima olumlu ve iyi bir şekilde seyretti etti. Örneğin 
Süleyman Barunî Paşa, ki kendisi Cezayirli değil Libyalıdır- ancak bir İbâdîdir, Osmanliya tabi idi. Baruni Paşayla ilgili Mehmet Mahfuz hocada bazı belgeler var, hoca onları çalıştı, dolayısıyla [durumun böyle olduğunu] biliyor.

Malumunuz Şeyh İtfiş adında çağdaş İbâdî müçtehit âlimlerinden bir zat var. Onun birçok kitabı ve tefsiri bulunmaktadır. Bu âlimin Osmanlıya yani Babı Aliye bağlı olmanın gerekliliği veya onlara vela göstermenin vucubiyetine dair risaleleri bulunmaktadır. Bu zatın Babu Ali'den aldığı ihsanları/hediyeleri/beraatları da mevcuttur.

Burada çok önemli bir nokta daha vardır. Adına Hariciler denilen kitle, fitne ve ümmet arasında sorunlar çıkarmakla meşgul olduklar1 için arkalarında herhangi bir ilimi birikim bırakmadılar. Bir yöntem veya usul ortaya koymadılar. Tetebbuata veya telifata önem vermediler. Herhangi bir ilim dalı geliştirmediler. İbâdîler bunun tamamen zıddına davrandılar. İbâdîlerin yazma veya matbu eserleri yani kitap hususundaki kültürleri binlerce eserle ifade edilmektedir. Yani onlar kendilerinden sonra binlerce eser biraktılar. Size örnek kabilinden bazı şeyler zikredeceğim. Onların bıraktığı, tefsir, hadis, fikıh hemen hemen bilinen bütün ilim dallarında hazine mahiyetinde binlerce esere havi bir mirastır. Örneğin Mevsuatu kamusi'şşeria'yı ele alalım. Bu eser doksan ciltten fazladır. Beyânu'ş-şer' yetmiş ciltten fazladır. Bunlar sadece birer örnektir. Musannef kırk cilttir. Az önce kendisinden bahsettiğimiz Şeyh iftiş, keza kendisinden bahsedeceğimiz Şeyh Selimî'nin eserleri aynen [böyle hacimli] çalışmalardır. Örneğin Şeyh İtfiş̧in üç adet tefsiri bulunmaktadır: Himyanu'z-zat, Teysiru't-tefsir, Dâi İla'l-amel olmak üzere. Yine onun fikıh sahasında Şerhu'n-nil adında bir eseri vardır ki 17 cilttir. Yaklaşık olarak yüz ayrı başlık altında yazdığı eserleri bulunmaktadır. Yazdıkları eserleri dikkatlice tetkik ettiğinizde İmamlardan, Buharî, Müslim, Ebû Hanife'den bahsettiğini, onların güçlü bir şekilde ve çokça bu eserlerde zikredildiklerini görürsünüz. Hatta zaman zaman İtfiş’in bazı konularda, kendi mezhebinin dişındaki zevat tarafından savunulan kimi görüşleri tercih ettiğini de görürüsünüz ki [az önce ifade ettiğim gibi] kendisi müçtehit bir âlimdir. Zaten bu 
mukayeseli fıkıh, İslam ümmetinin tamamına ait olup herkese açıktir.

Şimdi isterseniz İbâdîlerde bulunup da diğer düşünce ekollerinde bulunmayan nadirattan iki ilim dalından bahsedeyim. Bunlardan ilki İmu Mekâyis'l-curûh'tur. Bu ilim dalı birinin darbıyla yaralanan insanın ödemesi gereken diyetle ilgilenmektedir. Diğer düşünce ekollerinde bu mevzu fikıh kitaplarının bazılarında bölüm şeklinde yer alırken; İbdaîlerde ise müstakil bir ilim dalı olarak gelişmiştir. İkinci ilim dalı ise İmar Fıkhı'dır. Bu alan da İbâdîlerde müstakil bir ilim dalı olarak gelişmiştir.

M. Mahfuz SÖYLEMEZ: Üstadım verdiğiniz bu değerli bilgilerden dolayı müteşekkirim. Kendi adıma çok istifade ettiğimi söyleyebilirim. Doğrusu merak ediyorum. Her mezhep tarihi süreç içerisinde değiştiğine göre İbadaiye ne kadar değişmiştir? Bir başka ifade ile "Kadim Dönem İbâdîyyesi ile Modern İbâdîyye" arasında ne tür düşünsel farklılıklar bulunmaktadır?

Muhammed BABAAMMi: Kadim dönemi İbâdîyyesine baktığımız zaman mesela Halku'1-Kuran meselesi, Kelamcilar tarafindan bilinen, [çokça tartışılan meseleler] yani Rü'yetullah [Allah'ın ahirette görülüp görülemeyeceği] gibi meseleler akaidin usulünden sayılmaktaydı. Zaten bu meseleler aslında o dönemin ihtilafının esasını teşkil ediyordu. Ancak yakın dönem uleması bunların akaidin usulünden değil füruundan sayılması gerektiği ve bunların içtihat meselesine dâhil olduğuna kail olmuşlardır. Onlar akaidin usulünü ise bu tafsilatlara girmeksizin "saf tevhit" olarak görmüşlerdir. Bu mesele kadim dönem İbâdî uleması ile modern zaman İbâdî uleması arasındaki en temel fark olarak tebellür etmektedir. Kadim İbâdîyye ile Modern İbadîye arasındaki farklardan bir diğeri de Sahabeler arasındaki ihtilaflar -özellikle Sıffin ve diğer savaşlar- meselesidir. Bazı Kadim İbâdî kaynaklar zaman zaman bu mevzulara girmiş ve hatta bazen sert bazı tartışmalar da yürütmüşlerdir. Ancak modern dönem İbâdîyyesi bu tartışmalardan uzak durmaktadır. Bu gün "Bunlar [ümmet arasinda dökülen kanlardı] Allah kılıçlarımızı bu kanlara bulaştırmadt. Öyleyse biz de dilimizi temiz tutalım [bu mevzuya 
hiç girmeyelim; haklı ve haksızı Allah'a bırakalım] " anlayışını benimsemişlerdir. Dolayısıyla sahabe meselesine ayrıntılı olarak girmemeyi ve bu meselede tafsilata boğulmaktan uzak durmayı tercih etmektedirler.

M. Mahfuz SöYLEMEZ: Teşekkür ediyorum. Şunu sormak istiyorum. Günümüz İbâdîyyesinin diğer İslam mezhepleri ile ilişkileri nasıl? Bu konuda bize neler söyleyebilirsiniz? Siz de ifade ettiniz Uman'da İbâdîler Şafiilerle birlikte yaşıyorlar, Kuzey Afrika'da ise daha çok Malikilerle birlikte yaşıyorlar. Onlarla ilişkileri nasıl? Özellikle de İbâdîyye ile Şia arasındaki ilişkileri merak ediyorum. Bildiğiniz gibi geçmişe baktığınız zaman en çok bunlarla sorun yaşamışlard1. Bu konuda bize neler söyleyebilirsiniz?

Muhammed BABAAMMI: Kuzey Afrika ile başlayalım: Kuzey Afrika, neredeyse tamamen Malikî mezhebine mensuptur. Bu coğrafyada özellikle siyasî sahada ve diğer alanlarda İbâdîler ile Malikileri ciddi bir şekilde birbirlerinden ayırmanız mümkün değildir. Örneğin İbn Badis'in kurucuları arasında yer aldığı Cemiyyetu Ulema elMüslimîn adlı siyasi oluşum içerisinde İbâdîleri görebilirsiniz. Muhalif grubun içerisinde de örneğin Kuzey Afrika'da Hizbu Necmu Şimal İfrikiya ${ }^{2}$ içerisinde de İbâdîleri görmeniz mümkündür. Dolayısıyla tek cenahta yer almamakta, tek bir kanaat sahibi olarak görülmemektedirler. Aksine İbâdîlerin bütün bu cemiyetlerin tamamında diğerleriyle iç içe geçmiş vaziyette olduklarını müşahede edebilirsiniz. Dolayısıyla İbâdîlerin toplumsal sorunların tamamına, toplum katmanları ile birlikte çözüm aramaya çalıştıkları görülmektedir. Cezayir'in istiklal marşının yazarı olan Mufti Zekeriya İbâdî idi. [Dolayısıyla bu da Malikiler ile İbâdîler arasında ciddi bir kopukluğun olmadığının kanıtıdır.]

Mısır'a gidelim, bildiğiniz gibi Mısırlıların çoğunluğu Şafii mezhebine mensuptur. Onların Şafiilerle ilişkilerine bakalım: Mısır'da [Ce-

\footnotetext{
${ }^{2}$ Fransa'da 1926 yılında Cezayirli işçiler tarafından kurulmuştur. Sosyalist bir akımdir.
} 
zayir İbâdîlerinden olan] Şeyh Ebû İshak İbrahim et-İtfiş, İhvanu'lMüslimin'den önce kurulan [ve hatta] İhavana giden ilk basamak olan "Şubân el-Müslim'in" içerisinde, Hasan el-Benna ve diğerlerle birlikte yer alıyordu.

[Keza İbâdî kökenli olan] Amr Halife en-Namî Libyalı, tanınan bir şahsiyet olup İhavanı Müslimin'e mensuptu. Cezayir'de de İbâdîler arasında Teyyâr el-İslah adıyla bir akım gelişti, bunlar da İhvanu'l-Müslimin'e mensupturlar. Günümüzde [ise] İbâdîler örneğin Tunus'ta Zeytuniye medresesinde Şeyh Tahir b. Aşur, Fadıl b. Aşur ve diğer zevattın yanında eğitim gördüler. [Yani İbâdî olmalarına rağmen Sünni olan bu zevattın rahle-i tedrisinde eğitim görmekte beis görmediler]. Kanaatimce bu gün Kuzey Afrika'daki toplumsal kutuplaşmaya baktığınız zaman bu artık mezhepsel bir taksimi değil, aksine ideolojik bir kutuplaşmayı ifade etmektedir. Bunların içerisinde sosyalist, liberal, ulusalcı ve hatta İslamcı da bulabilirsiniz. Dolayısıyla taksim artık mezhebi bir taksim olmayıp ideolojik bir taksimdir. Bu ideolojik bölünme hemen hemen her mezhebin bünyesinde de bu şekilde meydana gelmiştir. Örneğin biz, bu salonun içerisinde oturanlar, farklı mezheplere mensup olsak bile sahip olduğumuz telakki ile [kendi mezhepdaşlarımızdan] komşularımızla sahip olduğumuz telakkiler farklı olabilir. Komşumuzun [bizimle aynı mezhebe mensup olsa bile] sosyalist, komünist veya bir başka ideolojiye mensup olması [pek ala mümkündür]. Dolayısıyla olay artık klasik anlamıla yüzde yüz mezhepsel bir hadise olmaktan çıkmıştır.

[Dahas1] burada bir başka konuya daha değinmek istiyorum: Mezheplerin ortaya çıkışı bir reel politiğin (vaki') sonucu idi. Ve bu reel politiğin bir sonucu olarak da savaşlar da meydana gelmişti. Ancak bu gün herhangi bir mezhebe mensup olmak, Müslümanlar arasında bir ihtilafa veya çatışmaya neden olmayı gerektirmemektedir. Aksine bizim bu mezhepsel bölünmenin varlığını kabul etmemiz, benimsememiz ve hatta sayg duymamiz icap eder. Hatta onun fikhıyla da amel edebiliriz. Yani Hanefi, Hanefi olarak kalabilir, Maliki de Maliki olarak kalabilir. Ancak Ümmetin maslahatı söz konu- 
su olduğunda ümmetin meşveret etmesi gerekir; biz artık bu klasik bölünmeyi aşmak zorundayız.

M. Mahfuz SöYLEMEZ: Çok Teşekkür ederim. İsterseniz biraz da İbâdîlere ait inanç esasları üzerinde duralım. İ̉âdîlere ait inanç esasları hakkında bize neler söyleyebilirsiniz?

Muhammed BABAAMMi: Salim b. Zekvân'ın risalelerini okuyanlar şunu görürler: İbâdîlerin inanç esaslarının tamamı Kur'an'ı kerimin ayetlerine dayanmaktadır. Tevhidin alametlerinin tamam Amene Resulü yani Bakara Suresinin sonunda yer alan ayetlerle belirlenmiştir. İşte İbâdîler bu inanç esaslarının tamamını kabul etmektedirler. Akide delaleti ve sübutu kat'i olan ilkelere dayanmaktadır. İbâdîler buna bir başka ilke daha ilave ederler ki o da Kur'an'a dayanmaktadır. Bu ilke de el-Velaye ve'1-Berae ilkesidir. Yani birini Allah için sevmek ve keza Allah için ondan nefret etmek. Kuşkusuz Kur'an'da buna işaret eden birçok ayet bulunmaktadır. Dolayısıyla İbâdîler bunu da inanç esaslarının içerine katmakta, inanç esaslarının bir parçası olarak ele almaktadırlar. İşte inanç esasları özü itibariyle bu şekildedir.

Ancak burada temel bir ihtilaf noktası da vardır. O da Şafaat mevzuudur. İbadiler temelde Peygamberler ile "Allah'ın şefaat etmesine izin verdiği zevatın" şefaat edebileceğine inanmaktadırlar. Ancak şefaatin sadece Müslümanlara uygulandığına; Müslüman olmayanların şefaatten faydalanamayacaklarına; şefaatin cehenneme girmesi vacip olan bir şahıs için geçerli olmadığına, şefaatin cennete girmeye hak kazanmış olan mü'minin derecesinin yükseltilmesine vesile olabileceğine inanmaktadırlar. İbâdîler ebedi Cennet ve ebedi Cehenneme de inanmaktadırlar. Onlara göre bir adam büyük günah işlerse, -küçük günah değil, büyük günah içlerse- ve de tövbe etmeden ölürse ebedi olarak cehennemde kalır. Tövbe etmeden diyorum, zira tövbe, velevki küfür dahi olsa kendisinden önce işlenmiş olan günahların tamamını siler, yok eder.

İbâdîlere göre fikıh usulünün kaynaklarına gelince: bunlar Kur'an, sünnet, icma ve kıyastır. Yani Ehl-i Sünnetin sırasiyla kabul ettiği kaynakların bizzat kendisidir. Bu temel konuların dişında 
kalanlar ise istihsan, seddu zirai gibi tabii veya ikincil kaynaklardır. Bunlarda, zaten diğer mezhepler de, ihtilaf etmişlerdir. Yani bunlar ihtilaflı mevzulardır. Zaten İbâdî Mezhebin içerisinde de bazı konularda ihtilaf bulunmaktadır ki bu da doğal bir durumdur. Örneğin İbâdîlerden bazıları Kur'an'nn mahlukluğunu kabul ederken bazıları da bunu reddetmektedirler. Aynı şekilde kulun ameli yani (efalu'lİbâd) meselesinde de bu ihtilaf mevcuttur. (yani kesb, cebr ve celb ${ }^{3}$ konusunda).

M. Mahfuz SÖYLEMEZ: Değerli dostlar Muhammed Babaammi hocaya sorusu olan arkadaşlarımız varsa onların sorularını alabiliriz. Buyrun Hüseyin Hocam.

Hüseyin KIR: Hocam öncelikle Çorum'a geldiniz, İbâdîler konusunda bilgimiz yoktu, bizi aydınlattınız, Allah razı olsun. Doğrusu merak ediyorum. İbâdîler Tasavvufa nasıl bakıyorlar?

Muhammed BABAAMMi: Soru için çok teşekkür ederim, konu çok önemli. Benim "İbâdîler ve Tasavvuf" diye bir makalem var. Keza [konuşmamin başında kendisinden bahsettiğim] İtfiş’in de "Esamu'l-Husnâ" adında bir kitabı var. Eser Allah'ın güzel isimleri ile ilgilidir. O bu kitabının 44. Sayfasında şöyle demektedir: "Bazılarl diyorlar ki: biz tasavvufu öğrendik ve denedik. Onun iyisi iyidir,

\footnotetext{
3 İtimadı kabul eden Mutezili alimler itimadı iki kısma ayırmışlardır. Bunlardan birincisine tabii lazım itimat (el-itimadu'l-lazimu't-tabiî) adını vermişlerdir. Ağır olan cismin aşağıya doğru gitmesi bu tür bir itimattır. Diğeri ise itme itimadtdır (el-itimadu'l- muctelibe)dir. Bu da; yukarıya doğru atılan ağır cismin yükseğe doğru gitmesi ağırlık itimadı ve aşağıya doğru hareket ettirilen hafif cismin hareket ettirildiği yöne doğru hareketinde olduğu gibi hafiflik itimadi şeklinde ikiye ayrılmaktadır. Kelâmcılar itimadın özellikleri hususunda ittifak sağlayamamışlardır. Fakat neden- sonuç ilişkisini açıklamada bu kavramdan istifade etmişlerdir. Neden- sonuç arasında zorunluluk görmeyen kelâmcılar yine de neden- sonuç arasında bir ilişkinin varlığını kabul etmişlerdir. Onlar itimadı sebep- sonuç arasındaki ilişkiyi açıklayan bir ilke olarak görmüşlerdir. İtimat ile ilgili geniş bilgi için bkz. Cüveynî, eş-Şamîl, s. 273; Âmidi, Ebkâr, s. $444 \mathrm{vd}$
} 
kötüsüde kötüdür. Tasavvufun Kuran'ı Kerim ve Hz. Peygamber [in ögretilerine] muvafık olan kısmı bizim katımızda da makbuldür. Ancak Kur'an'a ve hadise muvafik olmayan, onlarla çelişen kısmı ise bizim tarafimizdan da merfuddur, kabul edilmez, reddediler."

Büyük şairlerden kabul edilen Müslim er-Revâhî el-Umanî’nin şiirlerine dikkatinizi çekmek istiyorum. Onun tasavvuf ve zikir ile ilgili birçok kasidesi bulunmaktadır. İbâdîlerin içerisinde de aynen Ehl-i Sünnetin içerisinde var olduğu gibi mutasavvuflar veya tasavvufa mensup olanlar mevcuttur. Şeyh İtfiş'in Şerhu'n-nil adlı kitabının son bölümünün başlığ1 "Babu Tasavvuf" idi. Ancak burada bir sorun var. Bu eserin iki tane baskıs1 mevcuttur. Bu eserin M1sır'da Baruniye Matbaasında yapılan ilk baskısında böyleydi. Daha sonra İzzudin Beliğ tarafından tahkik edilerek neşredilen yeni baskısında bu başlık "babun fi tebyini efali'1-ibâd" şeklinde değiştirilmiştir. Doğrusu bu değişikliğin nedenini bilmiyorum. Ancak ilk baskısında bab başlığı bu şekilde idi. Dolayısıyla züht ile bezenmiş haliyle Tasavvuf güçlü bir şekilde İbâdîler tarafından da bilinmekte ve uygulanmaktadır. Özellikle de Kuzey Afrika İbâdîleri arasında.

M. Mahfuz SÖYLEMEZ: Peki İbâdîlerde tarikatlar veya büyük şeyhler var mi?

Muhammed BABAAMMi: Tabiki şeyhler var. Ancak tarikatlar yok, onun yerine halkalar var. Örneğin İbâdîlerde, Kuzey Afrika'da birçok yerde hala varlığını koruyan ve adına Azzabe denilen bir müessese bulunmaktadır. Bu müessese bir şeyh ve etrafında halka olan talebeler şeklinde kurgulanmıştır. Sonra onlar bu sistemi toplumun hizmetine tahvil etmişlerdir. Azzâbe kelimesi toplum hizmetleri ile iştigal den şahısların bu hizmetlerine mukabil ücret alamamalarını ifade etmektedir. Azzabe üyeleri geçimlerini, ücret alabilecekleri bir başka işten sağlamak zorundadırlar. Yoksa "azzabe" bekarlığ1 yani hiç evlenmemeyi ifade etmemektedir. Şayet teşkilatın üyesi toplum hizmetleri yürüttüğü zaman ücret alırsa bu onun konumunu belirlemiş olur. Dolayısıyla hakkı kabul veya reddetmesini ipotek altına alabilir. [Onun için ücret almaması gerekir]. 
Genel olarak İbâdîlerin tasavvuf ile bir çatışmaları bulunmamaktadır. Size daha ilgi çekici bir şey söyleyeceğim. Bilindiği gibi İmam Ebû Hamid el-Gazzalî'nin İhya Ulum ed-Din adında bir eseri bulunmaktadır ki tasavvufta temel bir perspektife (manzar) sahiptir. İmam Gazzali'den sonra yaşayan İsmail Numuzec el-Citarî adında bir İbâdî âlim, bu kitabı halka sunmak istemiştir. Ancak halkın Gazzalî'ye ait olan bu düşünceleri kendi fikirlerine muhalif göreceği ve dolayısıyla da red edeceklerinden korktuğu için, ona ait olduğunu söylememiş, özetleyerek [kendisine aitmiş gibi] takdim etmiştir. Özetlese de eserin aslı İhya Ulum ed-Din'dir. Yani İhya'nın ruhunun tamamının yer aldığı, mündemiç olduğu bir kitap. Bu özet kitabın adı Kanatiru'l-hayrât'dır. Bu eser basılmış olup bu gün hala elde mevcuttur. Doğal olarak bu eser İhyanın özeti olup tamamen tasavvufla ilgili bir çalışmadır ve bunu yapan da İbâdî kökenli bir şahıstır. Bu kitap aynen İhya gibi ders kitabı olarak okutulmakta, talebeler tarafından ezberlenmekte olup son derece meşhur bir eserdir.

Mesut OKUMUŞ: İmam Gazzali diyor ki "içerikte ittifak edilmesi durumunda lafızlara önem verilmez, itibar edilmez" [sizin anlattıklarınızdan tebellür etti ki] sizin Ehl-i Sünnet'ten bir farkınız bulunmamaktadır. Öyleyse kendinize neden İbâdî diyorsunuz ki?

Muhammed BABAMMi: İbâdîler, İbâdî adını kabul etmiyorlar. Şeyh Salim diyor ki "siz bizi bu isimle tesmiye diyorsunuz. Ancak biz bu ismi reddediyoruz" yani İbâdîler, [kendileri] için İbâdî adının kullanılmasını kabul etmemektedirler. Ancak İbâdî kavramı onlara siyasî olarak yapıştırılmış bir kavramdır. Yaygınlık kazanmaya başlanmış ve matbuatta da yazılmaya başlanmıştır. Yoksa İbâdîlerin kendileri bu ismi reddetmektedirler. Bu aslında açı ve belirgin bir mevzudur. 
Mesut OKUMUŞ: Peki öyleyse siz kendiniz için hangi ismi kullaniyorsunuz?

Muhammed BABAMMI: Biz kendimize Ehlu'd-Da'va ve'l-İstikame diyoruz. [Şunu da söyleyeyim] İbâdîler içerisinde bir akım var, bunlar Sünni eserleri ciddi bir şekilde okuyorlar ve bunlarla alakalı olarak aynı zamanda yazı da yazmaktadırlar.

\section{Dinleyicilerden biri: Türkiye'de İbâdî var mı?}

Muhammed BABAAMMI: Sünni dünyada İbâdîlerin varlığına gelince az önce kendisinden bahsettiğimiz Şeyh İbrahim İtfiş’i zikredebilirim. Ebû İshak İbrahim İtfiş, Mısır'da Daru'l-Ulûm'da hocalık yapiyordu. Burada İmam Kurtubî'nin ünlü tesiri olan el Câmi li Ahkami'l Kur'an ve'l-mübeyyin lima tedammenehu mine's Sünne ve ayi'lFurkân adlı kitabı tahkik ediyordu. Bu eserin ciltlerine bakacak olursanız muhakkik olarak Ebû İshak İbrahim İtfiş’in adını görebilirsiniz. Ki kendisi köken olarak İbâdî Mezhebine mensuptur. İtfiş hem İbâdî hem de Sünni kültürün tamamına hâkim bir âlim idi. Insanlar kendisine fetva sormaya gelirlerdi. Onlara hangi mezhebe mensup olduklarını sorar ve kendi mezheplerine göre fetva verirdi.

Başkasından mezhebini değiştirmesini talep etmek aslında matlup olan, istenen, arzulanan bir durum değildir. Asıl arzulanan durum insanın yüreğini Allah sevgisi (Hubbullah) için yumuşak hale getirmektir. Ben yaklaşık olarak üç yıldır Türkiye'de yaşıyorum. Birçok yere gittim, insanlarla birlikte yaşadım. Onlara hep şunu söyledim. "Ben aslında çoğu zaman aramızda bir fark göremiyorum. Ben bu imanı bu güzel ahlakı görüyorum. Aslında önemli olan da budur, bundan dolayı da mezhebi hiç araştırmıyorum." Türkiye, bu büyük hacmiyle, Müslüman bir ülke sayılmaktadır. Asıl önemli olan da budur. Dolayısıyla aslında hadisenin mezhepten çok daha önemli ve güçlü olduğunu düşünüyorum. Size Ebû Ubeyde ez-Zevavî'den bir kıssa anlatmak istiyorum. Oruç Reis ile Hayrettin Barbaros Cezayir'i İspanyollardan kurtarıp özgürleştirince Türkiye’ye dönmek istediler. Bakın anlattığım şey tarihi [gerçek bir hadisedir]. Ebû Ubeyde ez-Zevavî bu iki kardeşten birine diyor ki "Cezayir ya senin veya kardeşinin olacak ya da kurt tarafindan parçalanacaktır”. Öyle 
inanıyorum ki biz [İslâm ümmeti olarak] eğer bölünüp parçalanırsak her birimiz kurtlara yem olacağız.

Bir şey daha söylemem lazım: Cezayir'de İbâdîlerin karşı karşıya geldiği bir problem var. Aslında Malikiler de hatta Türkiye'de Hanefiler de bu sorunla karşı karşıyadırlar. Bu sorun da insanları tekfir eden, haktan uzaklaştıklarını söyleyen selefileşme sorunudur. [Maalesef] Selefileşme problemi İbâdîlerin içerisinde de bulunmaktadir.

Şiaya gelince İbâdîlerin Şiilerle direk bir teması bulunmamaktadır. Uman'da küçük bir Şii azınlık yaşamaktadır. İbâdîlerin Şiilerle bir sınırı da mevcut değildir. Dolayısıyla İbâdîlerle Ehl-i Sünnet arasında daha çok yakınlık vardır. Özellikle sahabe mevzuunda. İbâdîler de Şia'nın Hz. Ebûbekir, Ömer gibi sahabeye dil uzatmaları hususunda Ehl-i Sünnetle aynı hassasiyetlere sahiptirler.

Bir konuya daha dokunmak istiyorum. Bildiğiniz gibi sömürge döneminde İslam âleminin tamamı sömürgelere taksim edilmişti. Sömürge dönemi başlamazdan önce İslam âleminin tamamı Avrupa ülkeleri arasında pay edilmiş ve her bir üniversite bir bölge üzerinde araştırmalar yürütmüş, daha sonra da oraya müstemlekeciler girmişlerdir. Örneğin Cezayir İbâdîyyesi Polonya ile Rusya arasında yer alan WOW Ünivesitesi'nin payına düşmüştü. Bu Üniversite sadece Cezayir İbâdîyyesi üzerinde uzmanlaşmıştır, bu üniversitede İbâdîyye mezhebi araştırmalarına ayrılan bir kürsü vardır. İbâdî Araştırmaları Kürsüsü. Tabiki bütün bunları sömürmek amacıyla yapmışlardır. Bu üniversiteler ihtilaf konularını araştırıyorlar, çekişme doğurabilecek ihtilaf konularını. Bunu tespit edince de gruplar arasinda çatışmayı alevlendiriyorlardı.

Kanaatime göre eğer Müslümanlar daha önceki durumlarına geri dönmek istiyorlarsa birbirlerini tanımak zorundadırlar. Ali Yahya Muammer'in sözleriyle bitirmek istiyorum: O diyor ki" önce "ma'rife" birbirimizi tanıma, sonra "tearruf" tanış olma, arkasından da "i'tiraf" her mezhebin bir diğerinin sahip olduğu düşünceyi, doğruyu, hakkı itiraf etmesi ile bir birimize davranmamız gerekir." İște o zaman kendimizi bir tek ümmet olarak görebiliriz. Allah'n izniyle... 
M. Mahfuz SÖYLEMEZ: Evet değerli dostlar Muhammed BABAMMI hoca Umanlıların çokça kullandıkları Ali Yahya Muammer'in üçlemesi "marife, taarruf ve itiraf" ile bitirmiş oldu. Doğrusu bu üçlemeyi son zamanlarda ben de benimseyerek kullanyorum. İslami cemaatlerin öncelikli olarak yapmaları gereken durum bir birlerini tanımalarıdır. Hatta birbirlerini kendi kaynaklarından tanımaları gerekir. Şayet bu gerçekleşirse o zaman da artık tanış olmuş olur ve akabinde de her bir cemaatin diğer cemaatin sahip olduğu doğruyu, örnek alınabilecek güzelliği kabul edip itiraf etmesi icap eder. Kanaatimce ümmetin içinden geçtiği bu zor sürecin nedeni birbirimizi tanımaktan öte tanımlamamızdan kaynaklanmaktadır. Tanımladıkça da öteki ilan ediyoruz.

Bakın size bir hadise anlatayım ve bununla da bitirmiş olayım: Benim Nijeryalı bir öğrencim var. Benden Yüksek lisans yapıyor. Yazın memleketine gitti, kısa süre içerisinde gelip tezini teslim etmesi gerekiyordu. Nijerya'ya gittikten sonra birkaç kez kendisine ulaşmaya çalıştım, ancak muvaffak olamadım. Sonra bir gün çıktı geldi. Son derece sıkıntılı bir durumdaydı. Nedenini sorduğum zaman bana "Boko Haram cemaatinin kendi yörelerine saldırdığını, evli ve üç çocuk babası olan ağabeyini palayla boğazlayarak öldürdüklerini, kendisinin de mahsur kaldığını, bunun için gelemediğini söyledi". Benzer şeyleri İslâm âleminin birçok yerinde görmeniz mümkündür. Misır, Irak, Afganistan, Suriye ve Yemen'e bakmanız kâfi. Peki bu hadiselerin nedeni ne? Bunun üzerinde düşünmemiz gerekmez mi?

Evet değerli dostlar. Bununla iktifa ediyor, buraya gelip bize bu değerli bilgileri sunan Cezayir Metodoloji Enstitüsü'nün müdürü Prof. Dr. Muhammed BABAAMMî hocaya ve yaklaşık bir buçuk saattir, gözünü kırpmadan bizleri dinleyen siz değerli dinleyicilerimize; keza Programın gerçekleşmesindeki katkılarında dolayı dergimizin yazı işleri müdürü Murat ERDEM ve bu günkü sunucumuz aynı zamanda dergimizin yayın kurulu üyesi Mahmut YABACIOĞLUNA şükranlarımı sunuyorum. 
İslâmî İlimler Dergisi ve sahibi olan Çorum Çağrı Eğitim Vakfi'nın bir başka programında buluşmak üzere, Allah'a emanet olunuz diyorum 